\title{
Megalithism and Tribal Ritualism: A Passage through the Kurumbas of Attappadi
}

\author{
Manjula Poyil \\ Department of History, Nirmlagiri College, Kannur University, Kerala, India \\ Email: manjulapoyil@gmail.com
}

Received December 31 ${ }^{\text {st }}$, 2012; revised February $10^{\text {th }}$, 2013; accepted February $22^{\text {nd }}$, 2013

\begin{abstract}
Copyright (c) 2013 Manjula Poyil. This is an open access article distributed under the Creative Commons Attribution License, which permits unrestricted use, distribution, and reproduction in any medium, provided the original work is properly cited.
\end{abstract}

\begin{abstract}
The study of mortuary practices of Megalithic communities and its use as the basis for reconstructing the past society is unique in archaeology as it represents the direct and purposeful culmination of conscious behavior of the followers of this cultural trait. There are voluminous studies on the Megalithic builders of South India, including Kerala, written by prominent archaeologists and anthropologists from the early decades of the nineteenth century. Most of them ignored the continuity of Megalithic tradition, except a scant reference to the erection of funeral edifices among tribes like the Kurumbas and Mudugas of Attappadi and Mala-arayans of the Thiruvananthapuram district of Kerala. A study of the living Megalithic practices provides clues to ethnographic parallels, existing belief systems and habitation sites of the present communities. The present study discusses the cultural aspects of the rituals related to living Megalithic tradition among the Attappadi tribes, of the Palakkad district of Kerala. The study of the mortuary practices of the Kurumbas raises two important questions-firstly, how far this tribe can be seen as the actual successor of Megalithic builders of Kerala and, secondly, how does the social differentiation within the Kurumba community got reflected in its mortuary practices, just like the Megalithic builders of the past.
\end{abstract}

Keywords: Megalith; Kurumbas; Secondary Burial; Cheeru; Living Tradition

\section{Introduction}

The present study deals with the existence of Megalithic ${ }^{1}$ traits as a living tradition among the Kurumba tribe of Attappadi. The study of mortuary practices of Megalithic community and its use as a basis for reconstructing the past society is unique in archaeology because it represents the direct and purposeful culmination of conscious behavior of the followers of this cultural trait. There are several studies on the Megalithic traits of tribal communities in India (Hutton, 1992: pp. 242-249; Mawlong, 1990: pp. 9-14; Grigson, 1932; Bondo, 1950) but barring a few, most of the studies on the tribes of Kerala ignored the continuity of Megalithic tradition among tribes like the Kurumbas and Mudugas of Attappadi and Mala-Arayans of the Thiruvananthapuram district. A study of such living Megalithic practices provides clues to ethnographic parallels, existing belief systems and habitation sites of the present communities. The present study discusses the cultural aspects of the rituals related to living Megalithic tradition in Attappadi, the Palghat district of Kerala. A study of the mortuary practices of the Kurumbas raises two important questions-firstly, how far this tribe can be seen as the actual successor of Megalithic builders of Kerala and, secondly, how does the social differentiation within the Kurumba community got reflected in its mortuary practices,

\footnotetext{
${ }^{1}$ The word Megalith is derived from two words, Mega means big and Lith means stone. It is a custom of erecting huge funeral edifices over the relics of the dead. Along with the corpse all the belongings of the deceased are also deposited.
}

just like among the Megalithic builders?

Kerala, situated on the South-Western Coast of India, preserves the heritage of a rich Megalithic culture in the form of a wide variety of burial monuments and of a survival of megalithic cult among the various tribal communities who inhabit on the slopes of the western ghats, which still provides a pristine habitat for more than 36 varieties of tribal communities. Among these, Kurumbas have a close affinity with Megalithic communities because they erected funeral memorials only after the performance of an elaborate secondary burial. The Kurumbas, the most archaic among the 3 tribes of Attappadi (the other two being Irulas and Mudugas), lives in the dense forest adjoining the Silent Valley of Palghat district of Kerala, which is a part of the Nilgiri biosphere. There are two divisions among the Kurumbas-Palu-Kurumbas and Alu-Kurumbas. Alu-Kurumbas are concentrated in South-Western, Southern, South-Eastern and Eastern slopes of the Western ghats, and in the upper elevations of the Nilgiris. The Kurumbas of Attappadi are Palu-Kurumbas and they are concentrated in the lower elevations of the ghats. Both these groups are shifting cultivators and they used to live in separate hamlets. Each hamlet is a closely knit kin group with nuclear families. These tribal communities have an unfailing faith in animism and ancestor-spirits (Tylor, 1871: p. 424) which determined the nature of their mortuary practices, though slight changes existed between the two due a difference in the physical environment. There are 14 Palu-Kurumba hamlets scattered in different parts of south-western Attappadi. Among these Thodikki hamlet is the most prominent and has a com- 
manding position regarding funeral ritual related to all the hamlets. From the archaeological point of view Todikki acquires a predominant position because it is from here that reports about the Kurumba tradition of erecting dolmen-like Megaliths came first.

\section{Historiography}

Historical writings on the living tradition of Megalithic practice in Kerala are very few. Most of the studies are concentrated on the typology of monuments, their individual and common features, comparison with those of other parts of India and the world, and the belief systems associated with Megalithism. The first notable effort in this direction was made by L. A. Krishna Iyer, who studied extensively the Megalithic culture of the whole region of Kerala. He noticed, for the first time, the similarity between the ancestor worship of the Megalithic people and the tribal practices. In his two important works, The Prehistoric Archaeology of Kerala (Iyer, 1948) and Kerala Megaliths and their Builders (Iyer, 1967) as well as in his article The Disposal of the Dead among the Primitive Tribes of Travancore (Iyer, 1939: pp. 61-62), he pointed out that certain Travancore tribes like the Mala-Arayans erected dolmens over their graves like the Megalithic people. In his famous work, Travancore Tribes and Castes in 3 Volumes, he studied the burial customs of various tribes of Travancore and found that burial was the common mode of disposal of the dead and they deposited grave goods along with the corpse.

In his Early Man in Wynad (John, 1975: pp. 125-131) and The Megalithic Culture of Kerala, (John, 1978: pp. 485-489) K. J. John studied the survival of Megalithic culture among the lower caste Hindus and tribal communities of Malabar. He pointed out that majority of the tribes who live on the Western Ghats practice a burial custom which is very close to Megalithism of the ancient days. He argued that the cult of Muthappan and teyyam ritual dance is a cultural relic of the tribal tradition of ancestor worship.

Dieter B. Kapp in his remarkable article, "The Kurumbas' Relationship to the 'Megalithic' Cult of Nilgiri Hills (South India)" (Kapp, 1985: pp. 493-534) examined the past and present relationship of the Nilgiri Kurumbas towards megalithism. The most significant features of this article is that it presented the erection of dolmens, stone circles and various other lithic remains as a pointer to the cult of megalithism as a living tradition among them even today.

\section{Megalithic Traits in Kurumba Burial Practices}

\section{Disposal of the Dead}

"The onset of death is universally the subject of ritual, and there is not a single human society that simply throws the body out as a mass of decaying protoplasm” (Murphy, 1989: p. 211). And, for the Kurumbas, rituals are very elaborate, complex and weird. Their mortuary practices had three phases-pre-burial, burial and post-burial or secondary burial. According to Alekshin, the most important component of burial practice is ritualthe activities sanctioned by tradition that occur before, during, and after the burial and are considered essential to the transfer to the other world of deceased members of the community, both those forming its nucleus and others related by blood (Alekshin, 1987: pp. 137-138). Most important pre-burial ceremonies are announcement of death, purification ceremonies, funeral dance etc. Interment and mourning are the most common ceremonies of the second phase. Through interment the corpse is put inside the pit dug in the ground and the grave is filled, after inhuming the body inside it, with earth. Their graveyard, which is located away from the settlement in the forest, is known as Chodalai and graves are dug by expert gravediggers from the tribe. The grave is 6-feet deep and has a side cavity called Allekkuzhi, where the body of the deceased is placed and well protected with bamboo mats.

\section{Grave-Goods}

The corpse will be interred with a variety of goods including the personal possessions of two varieties-one domestic possessions of the deceased person like different kinds of food materials and water, clothes, ornaments, pottery, money, a cane basket known as tekku which contains different varieties of grains and second varieties are implements like knife, hoe, axe, spade, sickle, digging stick etc. Grains such as rice, millet, ragi, kora, thuvara, etc. also are mainly interred. Money is the token for the ferry charge to cross the river in the land of the dead for the spirit. After interment Kurumbas used to fix a stone as a burial mark at the head. All these grave goods gives us important historical clues like the type of their economy, type of metals used by them, their dietary pattern, anthropological data, belief in life after death etc.

\section{Social Differentiation}

It has been suggested that the social position of the departed is one of the important elements of the burial practices. It consists of the collection of material elements-the burial structure, the assemblage of grave goods, and the position of the deceasedrequired for a person of a particular age and sex to be transported to the other world (Alekshin, 1987: pp. 137-138). This social differentiation is reflected in mortuary ceremonies and clearly in the deposition of grave goods. The burials of infants are devoid of grave goods. On the basis of productive activities grave goods of men and women vary. Being an agricultural and hunting community, the Kurumba men are engaged in hunting and fishing and in various agricultural activities like ploughing while the women are involved in reaping, making baskets for keeping grains and digging tubers. Hence the most prominent grave goods deposited in men's graves are hoe, fish hooks, arrows, axe etc. whereas those in the graves of women are sickle, digging stick, needle and cane basket. Besides, a Kurumba woman is buried along with her precious and semi-precious ornaments. Thus their burial deposits appear to be richer than those of men.

\section{Secondary Funeral and Erection of Memorial}

The secondary burial ceremony of the Kurumbas is popularly known as Cheeru, (Poyil, 2009: pp. 31-38) which is protracted and very elaborate. Through this ceremony Kurumbas make necessary arrangements for the spirit's journey to the land of the dead. The Kurumbas called their spirit Nikal or shadow. The ceremonies connected with cheeru are spread over four days. This post-burial ceremony is conducted after the death of 101 members in a settlement; hence it took 10 to 20 years or more between two cheerus. This long interval between two 
cheerus is also caused by the huge expenditure incurred in celebrating this event. The prime ceremony is the collection of specific bones, i.e., clavicle, of the dead from the graveyard. The clavicle of the person who had died first after the last cheeru is collected first. A decorated funeral car known as gudikettu is constructed with a sacred chamber called gubbe at the bottom. The collected bones are kept inside the gubbe till the end of cheeru. The funeral rites are accompanied by funeral song, dance and music, feast and blood sacrifice.

At the end of the cheeru bones are taken to a sacred place known as nikalumalai or shadow-land, situated in the forest away from each Kurumba settlement, where the remains of the forefathers are kept. Then the bones are put inside a dolmenlike structure known among Kurumbas as malikai or matinati. A fitting farewell to the spirits is indispensable because the soul or nikal remains alive after death and it hovers around the hamlet to cause harm to the members of the entire hamlet. Hence it is essential to provide a permanent abode for the spirits.

\section{Conclusion}

Burial practices are significant archaeological sources for the analysis of past and present human societies. Thus knowledge of the living Megalithic tradition is helpful in unfolding the past history of early Iron Age communities. It would also enable us to trace out the antiquity of those communities who follow megalithism presently. In order to extract this information, tribal burials have to be excavated carefully and all the grave-goods accurately recorded so that a comparative investigation with tribal funerary ceremonies would be possible.

\section{REFERENCES}

Alekshin, V. A. (1983). Burial customs as an archaeological source. Current Anthropology, 24, 137-138. doi:10.1086/202960

Bondo, E. W. (1932). Highlander. London: Oxford University Press.

Grigson, W. (1950). Maria gonds of bustar. Oxford: Oxford University Press.

Hutton, J. H. (1992). The meaning and methods of erection of monoliths of Naga tribes. Journal of Royal Anthropological Institute, 52, 242-249.

John, K. J. (1975). Early man in Wynad. Journal of Kerala Studies, II, 125-131.

John, K. J. (1978). The megalithic culture of Kerala. In V. N. Misra, \& P. Bellwood (Eds), Recent advances in Indo-Pacific pre-history (pp. 485-489). New Delhi: Oxford and IBH Publishing Co.

Kapp, D. B. (1985). The Kurumbas' relationship to the "megalithic" cult of Nilgiri hills (South India). Anthropos, 80, 493-534.

Krishna Iyer, L. A. (1939). The disposal of the dead among the primitive tribes of Travancore. Man in India, XIX, 61-62.

Krishna Iyer, L. A. (1948). The pre-historic archaeology of Kerala. Trivandrum: L.K. Balaratnam.

Krishna Iyer, L. A. (1967). Kerala megaliths and their builders. Madras: University of Madras.

Mawlong, C. (1990). Classification of Khasi megaliths: A critic. Proceedings of Northeast India History Association, Imphal, 9-14.

Murphy, R. F. (1989) Cultural and social anthropology: An overture (3rd ed.). Eagle Wood Cliffs, NJ: Prentice Hall.

Poyil, M. (2009). Farewell ritual and transmigrating souls: Secondary funeral of the Kurumbas of Attappadi. The Anthropologist, 11, 3138.

Tylor, E. B. (1871). Primitive culture, I. London: John Murray. 